de los principales articuladores del movimiento que ya había iniciado Mario Baeza, perpetuándolo hasta nuestros días. Solo es posible agradecer este regalo, esta semilla que ha germinado, y honrar su ejemplo emprendiendo los más serios esfuerzos para el cultivo de la actividad coral en nuestro país y en el continente.

Julio Garrido Letelier

Facultad de Artes. Universidad de Chile julio.garrido.l@uchile.cl

\title{
Ariel Vicuña / Carlos de Bikunia / Selim Kartal (Valparaíso, 20 de septiembre de 1945 - Santiago, 20 de julio de 2017)
}

Cada ser humano es único y diferente a los demás, aunque el sistema actual en el que vivimos se esmere en someternos y uniformarnos según moldes estandarizados. Consciente de ello, Ariel Vicuña, durante los casi 72 años que vivió en este mundo, supo ser él mismo, celoso de su libertad. Fue su opción, que la ejerció en forma innata, intransable.

Consecuentemente, si bien su nombre completo es Carlos Ariel Fortunato Vicuña Navarro, para marcar la diferencia y evitar cualquier confusión, acaso a modo lúdico, él buscaba alternativas y seudónimos. De hecho, cuando era más joven, durante un tiempo se hizo llamar Carlos de Bikunia y, más recientemente, Selim Kartal, respondiendo a su carácter religioso y autoral.

Ariel fue el mayor de una familia de 7 hermanos: 2 mujeres y 5 hombres. Se crió en un ambiente singular, amable y acogedor, rodeado de artistas y libros. Su padre, José Miguel Vicuña Lagarrigue, era poeta y escritor de ensayos históricos; su madre, Eliana Navarro Barahona, era poetisa. Ambos trabajaron en la Biblioteca del Congreso Nacional y, entre otras iniciativas, crearon la sección de "libros raros y valiosos", todavía existente. En su casa acostumbraban a tener tertulias con ilustres visitas, como Nicanor Parra (que a veces se quedaba a alojar por varios días), Humberto Díaz-Casanueva y Óscar Hahn, entre otros; o a compositores como Humberto Maturana y Gustavo Becerra. En este contexto, tempranamente descubrió su vocación de poeta y músico.

De niño se caracterizó por ser un gran lector e investigador en la biblioteca de su casa, buscador de sorpresas literarias. Así llegó a leer -todavía en su infancia- Las mil y una noches (versión de J. C. Mardrus), libro que lo marcó de por vida. Producto de ello se convirtió al islam y entre los diversos colegios en que estudió (Colegio Mariano, Liceo Alemán, Liceo de Hombres...) creó un movimiento anticatólico, que llamó el "destinismo", doctrina basada en la predestinación. Sus compañeros seguidores se denominaban "los vicuñistas" y muchas veces, a modo de protesta, hacían huelgas y se resistían a entrar a clases. Todo esto -desconcertante para el orden establecido- finalmente generó que Ariel terminara sus estudios secundarios mediante exámenes libres. De esta manera, su vocación libertaria quedó manifiesta desde su juventud.

En relación con su desarrollo artístico, la poesía la aprendió en su entorno familiar, seguramente con cierta herencia genética y contagio ambiental, junto con su talento personal. Ya a los 11 años escribía poemas y en su vida llegó a publicar 6 libros (además de 2 inéditos que su familia espera publicar, dentro una compilación completa de su obra literaria). En el ámbito musical estudió piano, clarinete y oboe; también conoció el violín aunque no lo tocaba. Las clases de composición las tuvo con Sergio Ortega en la Escuela Vespertina de la Universidad de Chile, entre 1969 y 1970, y el desarrollo de su lenguaje musical finalmente lo llevó a explorar en el dodecafonismo. De hecho, en el último tiempo investigaba nuevos caminos para trabajar las series dodecafónicas, dividiéndolas en 2 "subseries de 6 notas", complementarias, generando en ellas diferentes formas de interacción. Incluso estaba empeñado en escribir un tratado acerca de su método, incluyendo temas como "disolución de la tonalidad", "principios armónicos atonales" y "saturación armónica”, con el título general de "Música atonal de principio dual". 
En cuanto a su repertorio, escribió música preferentemente de cámara, para instrumentos solistas, dúos, tríos, hasta quintetos y octetos. Algunas de sus composiciones, con formato de cámara grande, fueron interpretadas por el Conjunto de Música Moderna, de la Universidad de Chile, dirigido por Roberto Escobar (1974). En su catálogo figuran más de 20 obras, a partir de 1969, incluyendo Sinfonía Ilustración (1970). Editó y publicó 3 discos y, en el último de ellos, Música de cámara, aparece en la portada una foto de su rostro de niño, pintado al óleo por la artista argentina Marta Puebla, quien también participó en las tertulias de su casa familiar.

Selim Kartal, seudónimo que recuerda el universo esotérico de Las mil y una noches, nació el 20 de septiembre de 1945 en Valparaíso, y dejó este mundo recientemente, el jueves 20 de julio de 2017, en Santiago de Chile. Durante su vida siempre buscó ser diferente, apartado de las aglomeraciones humanas, y por ello desde niño evitó participar en los juegos habituales. Como adulto mantuvo esa misma actitud, ejerciendo su pasión creativa como poeta y músico, junto con diversos trabajos esporádicos, sea en calidad de empleado administrativo, vendedor de libros o profesor particular de música y matemáticas, custodiando así su independencia y camino propio.

De allí que en definitiva fuera un hombre solitario. Sin embargo, como contraparte, tenía una rica vida interior, multifacética, pues además de poeta y músico, pintaba a acuarela y témpera, junto con ser amante de la filosofía y la física. Con todo, él tenía un carácter tímido y retraído, aunque igualmente enamoradizo. Gracias a ello se casó y tuvo un hijo, pero su matrimonio no duró más de 2 años. Por otra parte, a nivel institucional, a pesar de su sentido de la libertad, ingresó a la Asociación Nacional de Compositores-Chile (ANC) y de vez en cuando participaba en sus asambleas, constantemente preocupado de estar al día en las cuotas.

Queda claro, entonces, que es difícil encasillar a Ariel Vicuña, desbordante, sea como poeta-músico o como músico-poeta. Y siendo tan especial como era, de bajo perfil, en buena hora supo registrar sus huellas en libros y partituras. Quizás por ello, poco antes de dejar este mundo manifestó estar muy tranquilo y contento con su vida, pacíficamente dispuesto a lo que viniera, sin miedo a la muerte. Así partió y se atrevió a continuar con una nueva aventura, más allá de las miles de noches que vivió en esta Tierra, ahora inmerso en otras esferas poético-musicales, siempre único y especial.

Gabriel Matthey Correa

Compositor, Chile

gmattheyc@hotmail.com

\section{Coriún Aharonián \\ (Montevideo, 4 de agosto de 1940 - 8 de octubre de 2017)}

En 1966 tuve la suerte de conocer a Coriún Aharonián. Se realizaba en Concepción (Chile) un curso de verano relativo a dirección coral y un festival nacional de coros organizados por la Asociación Coral Chilena en Santiago, junto con la Universidad de Chile ${ }^{1}$. Coriún, por entonces, era un joven director de coros uruguayo de 26 años, que había estudiado tempranamente musicología con Lauro Ayestarán, por quien tenía gran admiración y respeto. Además trabajó composición musical en su país con Héctor Tosar a partir de 1955 y posteriormente lo hizo con Luigi Nono gracias a una beca del gobierno de Italia.

Para resolver el problema del alojamiento de Coriún en la zona central de Santiago, asegurándonos que quedara cerca del teatro donde se realizaría el festival, me pareció que lo más adecuado era

1 El mismo Aharonián recordó cómo conoció al maestro García en RMCH LVII/200 (juliodiciembre 2003), p. 85. Referencias a aquel curso de verano en dirección coral, donde Aharonián estudió con Marco Dusi, en RMCHXX/95 (enero-marzo 1966), p. 57 (N. del E.). 